Metallophysics and Advanced Technologies

Металофіз. новітні технол.

Metallofiz. Noveishie Tekhnol.

2019 , vol. 41 , No. 1 , pp. $39-46$

https://doi.org/10.15407/mfint.41.01.0039

Reprints available directly from the publisher
(C) 2019 G. V. Kurdyumov Institute for Metal Physics, National Academy of Sciences of Ukraine Published by license under the G. V. Kurdyumov Institute for Metal PhysicsN.A.S. of Ukraine Publishers imprint. Printed in Ukraine.

PACS numbers: 06.60.Vz, 62.20.Qp, 68.35.Gy, 68.55.J-, 68.60.Bs, 81.15.Cd, 81.40.Pq

\title{
Development and Investigation of a Steel-Molybdenum Coating Deposited by the Gas-Thermal Method
}

\author{
V. I. Bolshakov, D. B. Hlushkova", O. V. Kalinin, O. I. Voronkov*, \\ and L. L. Kostina \\ Prydniprovska State Academy of Civil Engineering and Architecture, \\ $24^{a}$ Chernyshevsky Str., \\ 49600 Dnipro, Ukraine \\ "Kharkiv National Automobile and Highway University, \\ 25 Yaroslav Mudryy Str., \\ 61002 Kharkiv, Ukraine
}

The steel-molybdenum coating applied to the piston rings group made of high-strength cast iron provides a good conformability, low wear rate, and low coefficient of friction. This fact is explained by the specific characteristics of molybdenum oxides.

Key words: steel-molybdenum coating, conformability, wear rate, microhardness, molybdenum oxides.

Сталь-молібденове покриття, що нанесено на поршневі кільця з високоміцного чавуну, забезпечує добру припрацьовуваність, малу інтенсивність зношування, низький коефіцієнт тертя. Цей факт пояснюється специфічними властивостями окислів молібдену.

Ключові слова: сталь-молібденове покриття, припрацьовуваність, швидкість зношування, мікротвердість, оксид молібдену.

Сталь-молибденовое покрытие, нанесённое на поршневые кольца из высокопрочного чугуна, обеспечивает хорошую прирабатываемость, малую интенсивность износа, низкий коэффициент трения. Этот факт объясняется специфическими свойствами оксидов молибдена.

Corresponding author: Diana Borysivna Hlushkova

E-mail: diana@khadi.kharkov.ua

Citation: V. I. Bolshakov, D. B. Hlushkova, O. V. Kalinin, O. I. Voronkov, and L. L. Kostina, Development and Investigation of a Steel-Molybdenum Coating Deposited by the Gas-Thermal Method, Metallofiz. Noveishie Tekhnol., 41, No. 1: 39-46 (2019). DOI: $10.15407 /$ mfint.41.01.0039 
Ключевые слова: сталь-молибденовое покрытие, прирабатываемость, скорость износа, микротвёрдость, оксиды молибдена.

(Received September 9, 2018)

\section{ANALYSIS OF PUBLICATIONS}

The significant increase of reliability and endurance of units and machine parts is one of the main problems in the development of modern engineering.

This problem can be solved by the urgent development of the new technologies, especially, for the details, which work in the condition of friction as well as amortization.

The well-known strengthen technologies have some disadvantages, for example: the microgeometry of details is changed after strengthening, skellering of the product surface and the appearance of stresses inside it, affects the operability of the machine unit, the need to create special and expensive conditions for the process of strengthening, environmental problems, etc.

This scientific research is devoted to the process of planning and investigation of the structure and features of piston rings group after covering them with steel-molybdenum coating.

\section{MATERIAL AND METHODS OF RESEARCH}

The coatings were applied to the piston rings group made of highstrength cast iron used in batch production.

Now, the electrolytic bichromated coating is applied to the piston rings group.

That is why the researches were conducted simultaneously with the piston rings group, which were reinforcement according to the proposed technology of hardening; the results of the research were compared by the main features, which characterize serviceability of piston rings group during operation.

The proposed technology of hardening consists in applying a coating on cast iron rings by the method of double-wire metallization with independent feeding of steel and molybdenum wires. For this purpose, structural bearing steel $11 \mathrm{X} 18 \mathrm{M}$ was selected, the chemical composition of which is given in Table 1.

TABLE 1. Chemical composition of steel 11X18M (content of elements, \%).

\begin{tabular}{c|c|c|c|c|c|c|c|c|c}
\hline $\mathrm{C}$ & $\mathrm{Si}$ & $\mathrm{Mn}$ & $\mathrm{S}$ & $\mathrm{P}$ & $\mathrm{Cr}$ & $\mathrm{Mo}$ & $\mathrm{Cu}$ & $\mathrm{Ni}$ & $\mathrm{Fe}$ \\
\hline
\end{tabular}


Molybdenum is chosen as a material having a melting point of $2620^{\circ} \mathrm{C}$, high heat resistance and corrosion resistance, low thermal expansion coefficient, high hardness and strength at elevated temperatures, significant specific strength. Such a set of properties can significantly improve the quality of the coating.

The method of two-wire metallization creates a complex structure of the coating, in which particles of steel and molybdenum, having different properties (including density), should be distributed in successive layers with different hardness. This will allow obtaining a heterogeneous structure of the coating, ensuring its high antifriction properties.

The piston rings, which were covered with the steel-molybdenum coating, were grouped in twenty items. The assembling of the piston rings group was carried out in a special appliance, imitating the bushing of the working cylinder. Rings on the mandrel were assembled in such a way that there was no opening of the locks.

On the working surfaces of the piston rings group, a special groove is provided under the coating, which increases the adhesion of the coating to the substrate.

The technological process of applying the steel-molybdenum coating to the piston rings group includes the following stages: preliminary cleaning, bead blasting treatment, spraying.

The bead blasting treatment deals with cleaning the surface of the base coat increase the surface roughness of the substrate, which in-

TABLE 2. The modes of steel-molybdenum coating sputtering.

\begin{tabular}{|c|c|c|c|c|c|c|c|c|c|c|c|c|c|c|}
\hline \multicolumn{2}{|c|}{$\begin{array}{c}\text { Coating } \\
\text { composi } \\
\text { tion, } \\
\% \text { wt. }\end{array}$} & \multicolumn{2}{|c|}{$\begin{array}{c}\text { Wire } \\
\text { diame- } \\
\text { ter, mm }\end{array}$} & \multicolumn{2}{|c|}{$\begin{array}{c}\text { Wire } \\
\text { feed } \\
\text { speed, } \\
\mathrm{m} / \mathrm{min}\end{array}$} & \multicolumn{2}{|c|}{$\begin{array}{c}\text { Coating } \\
\text { composi- } \\
\text { tion, } \\
\% \text { in } \\
\text { volume }\end{array}$} & \multirow[t]{2}{*}{$\begin{array}{l}p \\
00 \\
80 \\
\Phi \\
\pm 0 \\
0 \\
0 \\
0 \\
\dot{4}\end{array}$} & \multirow[t]{2}{*}{ 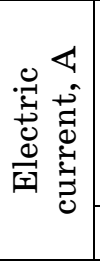 } & \multicolumn{2}{|c|}{ 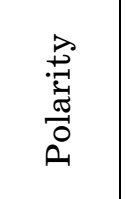 } & \multirow{2}{*}{ 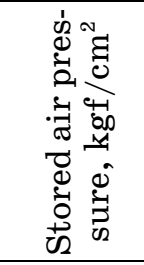 } & \multirow{2}{*}{ 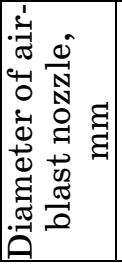 } & \multirow{2}{*}{ 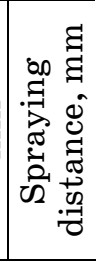 } \\
\hline Mo & St & Mo & $\mathrm{St}$ & Mo & St & Mo & $\mathrm{St}$ & & & Mo & $\mathrm{St}$ & & & \\
\hline 50 & 50 & 1.5 & 1.7 & 3.8 & 3.8 & 44 & 56 & 35 & 220 & + & - & & 7 & $\begin{array}{c}100- \\
110\end{array}$ \\
\hline 50 & 50 & 2.0 & 2.3 & 3.8 & & 44 & 56 & 40 & 100 & + & - & & & $\begin{array}{c}100- \\
110\end{array}$ \\
\hline 60 & 40 & 1.5 & 1.7 & 3.8 & & 53 & 47 & 35 & 220 & + & - & $50-5$ & 7 & 110 \\
\hline 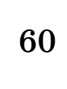 & 40 & 2.0 & 2.3 & 3,8 & & 53 & 47 & 40 & 250 & + & - & 0.00 .0 & 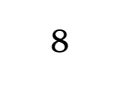 & $\begin{array}{c}100- \\
110\end{array}$ \\
\hline 40 & 60 & 1.5 & 1.7 & 3.8 & 5.84 & 33 & 67 & 35 & 220 & + & - & & 7 & $\begin{array}{c}100- \\
110\end{array}$ \\
\hline \pm 0 & 60 & 2.0 & 2.3 & 3.8 & & 33 & 67 & 40 & 400 & + & - & $5.0^{-}$ & 8 & $\begin{array}{c}100- \\
110\end{array}$ \\
\hline
\end{tabular}


creases the total area of the coating adhesion sections with the substrate and the adhesion of the coating.

Molybdenum and steel wires were fed at a certain speed. The coating was applied by electric arc spraying on the same mandrel as shot blasting. The molybdenum wire is connected to the positive pole of the power source, the steel wire to the negative pole.

The application modes of the steel-molybdenum coating are given in the Table 2.

The temperature of the piston rings group during the application of the steel-molybdenum coating is $150^{\circ} \mathrm{C}$. The coating was sprayed to a thickness of $0.8 \mathrm{~mm}$. After the coating was applied, a mechanical treatment was carried out. The thickness of the coating in the final finished ring is $0.5 \pm 0.1 \mathrm{~mm}$.

\section{THE RESULTS OF THE CONDUCTED RESEARCH}

The structure of the steel-molybdenum coating was studied using a metallographic microscope with an increase from $\times 100$ to $\times 300$.

The microstructure of the coating has a typical character of gas thermal coats layered with uniformly spaced pores (Fig. 1).

The industrial etching of the samples was carried out with a $\mathrm{Mu}$ rakama reagent $\left(10 \mathrm{~g} \mathrm{NaOH}, 10 \mathrm{~g} \mathrm{~K}_{3} \mathrm{Fe}(\mathrm{CN})_{3}, 10 \mathrm{ml} \mathrm{H}_{2} \mathrm{O}\right)$, which is used to reveal the structure of Mo and other refractory materials.

The structure of the steel-molybdenum coating after etching is shown at the Fig. 2. The microstructure of the coating is a combination of molybdenum (dark, etching areas) and steel (light, non-etching areas).

The large-dispersed component of molybdenum appears with a larger increase in the structure of the coating, apparently, due to the high rates of crystallization during the coating process (Fig. 3). Besides the two main phases, the other structural components are observed in the coating, which are to be the products of the interaction of steel and mo-

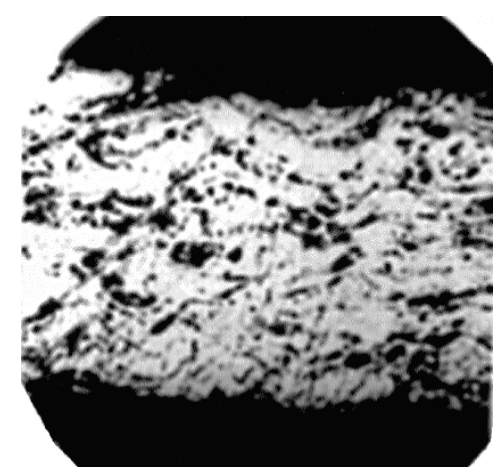

Fig. 1. The microstructure of steel-molybdenum coating, $\times \mathbf{1 1 5}$. 


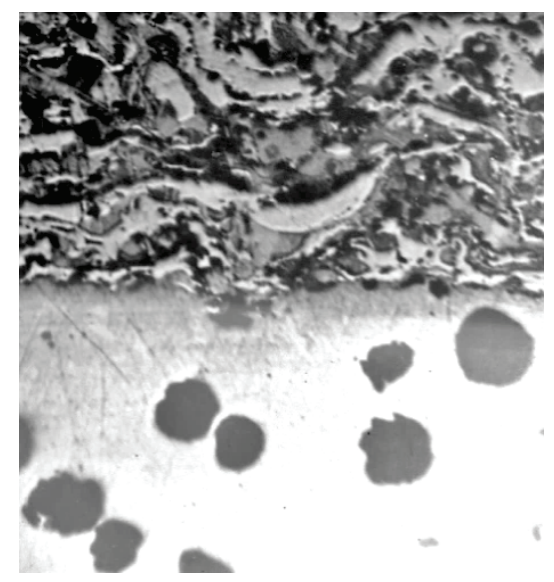

Fig. 2. The microstructure of steel-molybdenum coating after etching, $\times \mathbf{1 1 5}$.

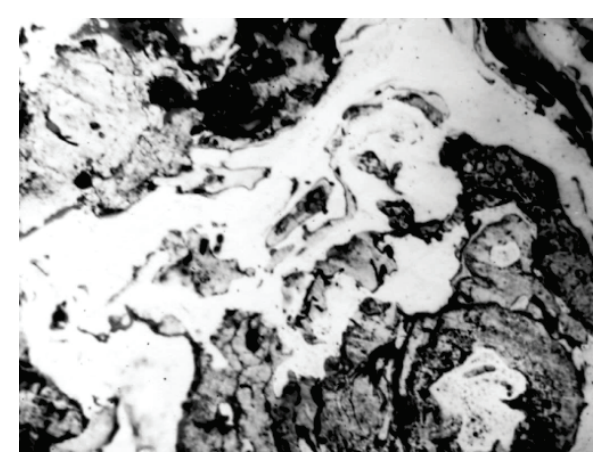

Fig. 3. The microstructure of steel-molybdenum coating surface layer, $\times 400$.

lybdenum wires with oxygen and nitrogen, as well as products of interaction between molybdenum and steel in the process of plasma spraying.

The pore size of the coating is $(5-10) \cdot 10^{-6} \mathrm{~m}$ that is optimal for piston ring group operating with significant force and temperature loads.

The porosity of the coating (up to $12 \%$ ) provides an increased oil consumption of the rings, which positively affect both the process of running-in of the working sleeve-piston ring pair and the operation of the piston ring group during operation.

The control of the adhesion strength of the steel-molybdenum coating to the substrate is carried out on a special device by twisting the piston ring group with simultaneous bending until the coating was peeled off. The angle of twist at which the coatings were peeled off is not less than $35^{\circ}$, which indicates satisfactory adhesion of the coatings.

The measurement of microhardness showed that, for molybdenum, 
it is $H_{\mu}=550-590$, and for steel, $H_{\mu}=460-560$ by the thickness of the coating.

The microhardness of molybdenum increased to $H_{\mu}=720-760$, and steel, $H_{\mu}=520-580$ after the tests for wearability.

In order to determine the antifriction properties of the obtained steel-molybdenum coating of piston ring group and the propensity to grasp it with the sleeve, the tests were conducted to determine the dependence of friction coefficient on the load. Samples cut from the chrome and the steel-molybdenum ring group were tested, when rubbing in pair with disc samples from cast iron. The investigations were carried out by using a SMC-2 friction machine under step loading. Lubrication with oil was carried out by dipping as well as applying it to the working surfaces of the samples before testing. The results of the tests are shown in Table 3.

The obtained data indicate that the steel-molybdenum coating does not adhere to the sleeve cast iron in the entire range of loads. Moreover, when rubbing under more severe conditions (with a single lubrication before the test), the friction coefficient at high loads is even less than with excessive lubrication. At the same time, samples of chromium-plated rings can withstand less stresses prior to bulging working under more severe conditions.

Thus, the obtained results indicate a higher resistance to corrosion and better antifriction characteristics of piston rings with a steelmolybdenum coating in comparison with electrolytic chromium plating.

The durability tests were carried out in comparison with chromeplated piston rings in order to determine the wearability and wear resistance of a steel-molybdenum coating, when it was paired with a sleeve. The test was carried out on a CMC-2 machine with reciprocating motion for two hours under load $1 \mathrm{kN}$ and a sliding speed of $1.3 \mathrm{~m} / \mathrm{h}$. Lubrication is made by means of the immersion in oil.

The wear rate by the mass of the disc (liner) and the shoe (ring)

TABLE 3. Dependence of friction ratio on the load.

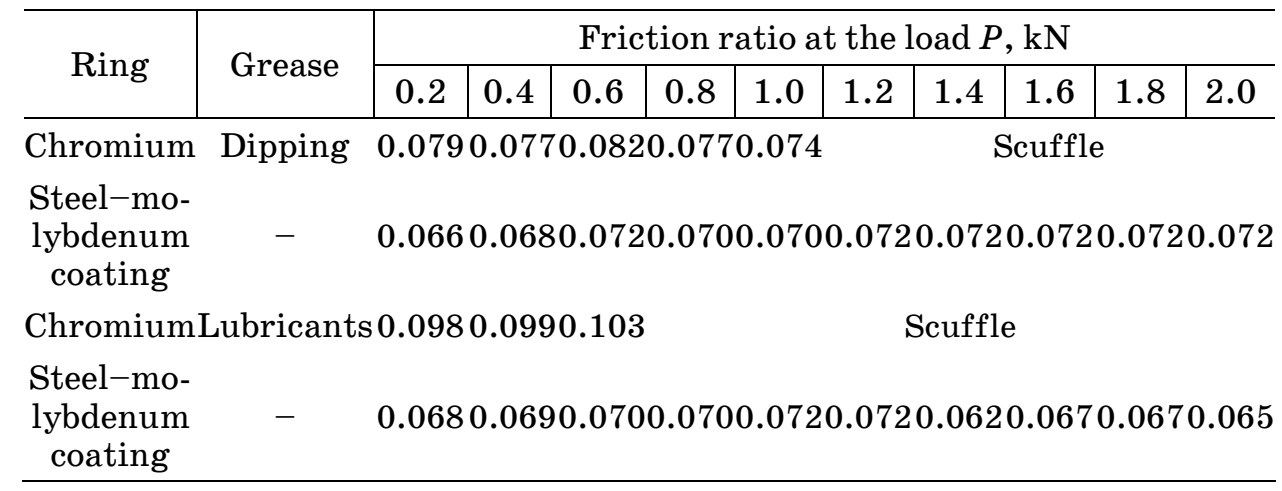


treated by the existing technology (electrolytic chromium plating) as well as after the application of the steel-molybdenum coating are presented for comparison of the histogram in Fig. 4.

The results indicate that the steel-molybdenum coating is more wear-resistant than electrolytically chrome plated one. The steelmolybdenum coating minimizes the mating material to a lesser extent and has a lower coefficient of friction

In Figure 5, the dependence of the wearability of the piston ring group, chromed and with a steel-molybdenum coating, on the test time is depicted.

The analysis of the obtained results testifies to faster workability of piston ring group with the steel-molybdenum coating. For a piston ring group with a steel-molybdenum coating, a lower wear rate is also characteristic, which is confirmed by the obtained data on the good antifriction properties of these coatings.
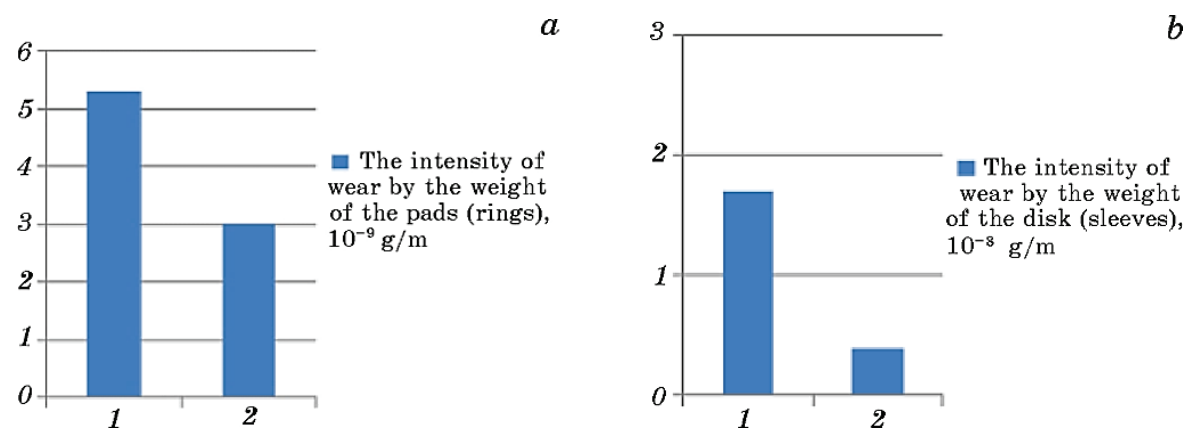

Fig. 4. Histogram of the intensity of wearability by weight of the pads (rings) $(a)$ and the disc (sleeves) (b); 1 -chrome plated coating; 2-steel-molybdenum coating.

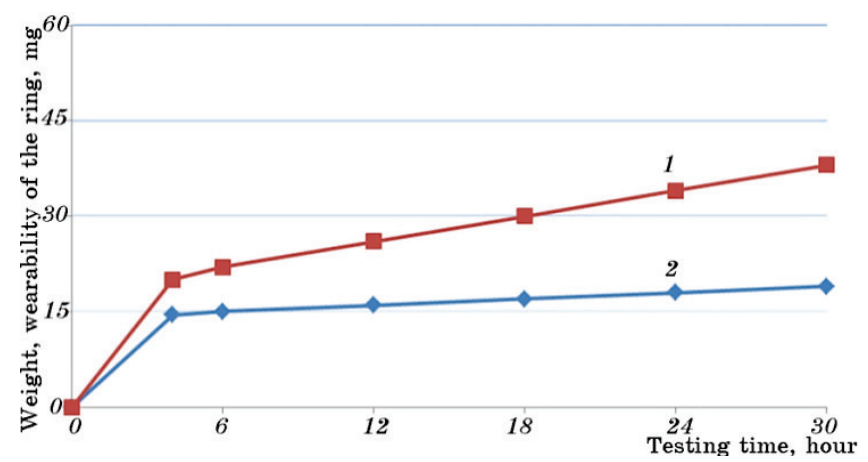

Fig. 5. Dependence of wearability of piston ring group on test time: 1 -chrome ring; 2 -ring with steel-molybdenum coating. 
Such a complex of parameters of steel-molybdenum coating can be explained by the specific properties of molybdenum oxides, which can have an additional lubricating effect, acting as a solid lubricant. In addition, the high melting point of molybdenum $\left(2600^{\circ} \mathrm{C}\right)$ contributes to a lesser propensity to grasp (weld) the mating/matched materials.

The difference in the parameters of the crystalline structure of molybdenum and $\mathrm{Fe}_{\alpha}$, which is the base of the metallic matrix of cast iron facilitated decrease in setting. Molybdenum crystallizes with the formation of a body-centred cubic lattice with a period $a=3.1474 \AA$, whereas in $\mathrm{Fe}_{\alpha} a=2.8665 \AA$ (in chromium, the lattice period is $a=$ $=2.8829 \AA$ ).

\section{SUMMARY}

1. The technology for applying a steel-molybdenum coating is proposed.

2. The investigation of a steel-molybdenum coating structure showed that it has a heterophase structure.

3 . The porosity of a steel-molybdenum coating provides increased oil consumption of the rings, which positively affects the process of running in of the working cartridge-piston ring pair.

4. The coefficient of friction of the steel-molybdenum coating is $20 \%$ lower than that of the chrome-plated coating for all the studied loads.

5 . The wear rate of the chrome ring is by 2 times higher than that of the ring with a steel-molybdenum coating.

6 . The piston ring group with a steel-molybdenum coating are characterized by faster workability than rings with chrome-plated coating.

7. The basis for a higher complex of antifriction properties and wear resistance of piston rings with a steel-molybdenum coating as compared to chrome plated is given.

\section{REFERENCES}

1. V. V. Kudinov, The Theory and Practice of the Gas-Thermal Coating (Moscow: Metallurgy: 2000) (in Russian).

2. E. V. Antoshin, Application of Metallic and Non-Metallic Coatings by Means of Gas-Thermal Spraying (Moscow: Engineering: 2002) (in Russian).

3. N. V. Katz, Metal Pulverization (Moscow: Engineering: 2006) (in Russian). 